\title{
KEADILAN SOSIAL DALAM KEUANGAN SYARIAH
}

\author{
M. Roem Syibly \\ Program Studi Hukum Islam FIAI, Universitas Islam Indonesia, Yogyakarta \\ Email: roemsyibly@gmail.com
}

\section{Abstract}

Social justice in the Islamic economy is based on spiritual commitment and the concept of universal brotherhood among human beings which requires that all resources be sacred trust God, used to realize Maqashid Shari'ah, it is the fulfillment of human life. This paper describes the theory of social justice that focus on Islamic financial. The foundation of Islamic justice can be seen from al-Qur'an Surah al-Hadid: 25 affirming that justice has been emphasized by the Qur'an as the primary mission of the Prophets sent by God Almighty, including economic justice and the elimination of the income gap. Social justice in Islam is the implication of the fundamental principle underlying all the teachings of Islam, namely monotheism. At the level of practice, Islam prohibits usury, Islam seeks to build a society based on honesty and fairness. Justice in this context has two dimensions, namely the financiers are entitled to a reward, but should be commensurate with the risk and effort required, and the reward is determined by the profit. Implementation of Islamic justice theory in Islamic finance can be seen from mudharabah and Musharaka or commonly known as a profit and loss sharing.

\section{تجريد}

كانت العدالة الاجتماعية في الاقتصاد الإسلامي تعتمد على الالتزام الروحي ومفهوم الأخوة العالمية بين البشر مما يستلزم من جميع الموارد الإيمان المقدس بالله وحده، وتُستخدَم لتحقيق مقاصد الشريعة حيث أنه تحقيقا للحياة البشرية. وتصف هذه المقالة نظرية العدالة الاجتماعية التي تركز على التمويل الإسلامي. ويمكن ملاحظة أساس العدالة الإسلامية من خلال سورة الحديد: الآية هب مؤكدة أن العدالة قد تم تأكيدها من قبل القرآن كالمهمة الرئيسية للأنبياء التي أرسلها الله 
سبحانه وتعالى، بما في ذلك من العدالة الاقتصادية والقضاء على الفجوة في الدخل. كانت العدالة الاجتماعية في الإسالام هي الآتار المترتبة على المبدأ الأساسي الذي يرتكز عليه التعاليم الإسامية، وهي التوحيد. وعلى مستوى التطبيق، فالإسلام يحرم الربا، ويسعى إلى بناء بحتمع يقوم على الصدق والعدل. والعدالة في هذا السياق هلا بعدان، وهما (1) يمق الممولين لمكافأة، ولكن ينبغي أن تتناسب مع المخاطر والجههد المطلوب، و(r) يتم تحديد مكافأة من الربح. إن تنفيذ نظرية العدالة الإسامية في التمويل الإسلامي يمكن ملاحظته من المضاربة والمشاركة أو المعروف عموما باسم تقاسم الربح والخسارة.

Keywords: Kata kunci: keadilan sosial, ekonomi Islam, dan keuangan Islam.

\section{A. Pendahuluan}

Salah satu sumbangan terbesar Islam kepada umat manusia adalah adanya prinsip keadilan sosial yang dilaksanakan dalam setiap aspek kehidupan manusia. Setiap anggota masyarakat didorong untuk memperbaiki kehidupan material masyarakat tanpa membedakan bentuk, keturunan dan jenis orangnya. Setiap orang dipandang sama untuk diberi kesempatan dalam mengembangkan seluruh potensi hidupnya. ${ }^{1}$

Islamadalahagamayang rahmatan lil 'alamiin. Artinya ajaranIslamakandapat diterapkan atau dipakai siapa saja, dan di mana saja. Rahmatan lil'alamiin adalah sebuah konsep yang mengandalkan pada konsep keadilan. Keadilan merupakan isi kandungan yang tidak dapat dihilangkan dari keyakinan Islam, sehingga kondisi ideal masyarakat Islam tidak akan dapat tercapai apabila keadilan tidak ditegakkan. Islam ingin menjinakkan semua perilaku dzalim dari masyarakat. Termasuk di dalamnya adalah perilaku dzalim masyarakat bisnis. Perilaku dzalim adalah perilaku-perilaku dalam bentuk diskriminasi, ketidakadilan,

1 Afzalur Rahman, Doktrin Ekonomi Islam, jilid 1, Terj. Soeroyo, Nastangin, (Yogyakarta: PT. Dana Bhakti Wakaf, 1995), hal. 74 
eksploitasi, tekanan, dan perilaku sewenang-wenang yang dengan perilaku ini dapat merugikan orang lain.

Keadilan masyarakat merupakan keadilan ideal, di mana masyarakatnya dapat hidup dengan layak dalam berbagai bidang. Tidaklah mungkin untuk mendapatkan masyarakat Islam yang ideal sementara keadilan tidak ditegakkan. Berdasarkan paparan ini, satu hal yang tidak dapat dihindari dari keyakinan lslam bahwa manusia merupakan khalifah (wakil) Tuhan, dan manusia harus mengatur hidup sesuai dengan status mereka. Pengarahanpengarahan yang terkandung dalam ajaran-ajaran Islam adalah dalam rangka membantu merealisasikan tujuan ini.

Para ulama sangat percaya bahwa kesejahteraan umat dan peringanan mereka dari beban hidup yang berat merupakan tujuan dasar syariah. Pandangan ini, jika dilihat dari sudut pandang ekonomi merupakan penekanan pada penciptaan kelayakan ekonomi melalui pemenuhan kebutuhan dasar dan penciptaan keadilan sosio-ekonomi. Dari sinilah diperlukan suatu penanganan dan pendekatan serta studi yang berorientasi sosial, sehingga seluruh fungsi perusahaan harus berlandaskan pada nuansa lslami. ${ }^{2}$

Keadilan sosial ekonomi dalam Islam, selain didasarkan pada komitmen spritual, juga didasarkan atas konsep persaudaraan universal sesama manusia. Al-Quran secara eksplisit menekankan pentingnya keadilan dan persaudaraan tersebut. Menurut M. Umer Chapra, sebuah masyarakat Islam yang ideal mesti mengaktualisasikan keduanya secara bersamaan, karena keduanya merupakan dua sisi yang sama yang tak bisa dipisahkan. Dengan demikian, kedua tujuan ini terintegrasi sangat kuat ke dalam ajaran Islam sehingga realisasinya menjadi komitmen spritual (ibadah) bagi masyarakat Islam.

Komitmen Islam yang besar pada persaudaraan dan keadilan, menuntut agar semua sumber daya yang menjadi amanat suci Tuhan, digunakan untuk mewujudkan maqashid syari'ah, yakni pemenuhan kebutuhan hidup manusia, terutama kebutuhan dasar (primer), seperti sandang, pangan, papan, pendidikan dan kesehatan. Persaudaraan dan keadilan juga menuntut agar sumberdaya didistribusikan secara adil kepada seluruh rakyat melalui kebijakan yang adil

2 Kariyoto, "Akuntansi Syariah dalam Perspektif Teori dan Implementasinya”, dalam jurnal JIBEKA, vol. 8, No. 2, Agustus 2014, hal.25 
dan instrumen zakat, infaq, sedekah, pajak, kharaj, jizyah, cukai ekspor-impor dan sebagainya. ${ }^{3}$

Dalam paper ini, penulis menjelaskan teori keadilan sosial yang fokus pada keuangan syariah. Sebelum pada fokus bahasan, dijelaskan lebih dahaulu tentang teori keadilan dalam Islam secara umum, dan teori keadilan dalam ekonomi Islam.

\section{B. Teori-teori Kadilan}

Terdapat macam-macam teori mengenai keadilan dan masyarakat yang adil. Teori-teori ini menyangkut hak dan kebebasan, peluang kekuasaan, pendapatan dan kemakmuran. Di antara teori-teori itu dapat disebut: teori keadilan Aristoteles dalam bukunya nicomachean ethics dan teori keadilan sosial John Rawl dalam bukunya a theory of justice. Di samping itu juga terdapat teori keadilan hukum Islam.

\section{Teori keadilan Aristoteles (Kesamaan Proporsional)}

Pandangan-pandangan Aristoteles tentang keadilan bisa kita dapatkan dalam karyanya nichomachean ethics, politics, dan rethoric. Lebih khususnya, dalam buku nicomachean ethics, buku itu sepenuhnya ditujukan bagi keadilan, yang berdasarkan filsafat umum Aristoteles, mesti dianggap sebagai inti dari filsafat hukumnya, "karena hukum hanya bisa ditetapkan dalam kaitannya dengan keadilan". ${ }^{4}$ Yang sangat penting dari pandanganya ialah pendapat bahwa keadilan mesti dipahami dalam pengertian kesamaan. Namun Aristoteles membuat pembedaan penting antara kesamaan numerik dan kesamaan proporsional. Kesamaan numerik mempersamakan setiap manusia sebagai satu unit. Inilah yang sekarang biasa kita pahami tentang kesamaan dan yang kita maksudkan ketika kita mengatakan bahwa semua warga adalah sama di depan hukum. Kesamaan proporsional memberi tiap orang apa yang menjadi haknya sesuai dengan kemampuannya, prestasinya, dan sebagainya. Dari pembedaan ini Aristoteles menghadirkan banyak kontroversi dan perdebatan

3 Keadilan dalam Ekonomi Islam, dikutip dari http://wardahcheche.blogspot.com diakses pada 12 Okbober 2014.

4 Carl Joachim Friedrich, Filsafat Hukum Perspektif Historis, (Bandung: Nuansa dan Nusamedia, 2004), hal. 24. 
seputar keadilan. Lebih lanjut, dia membedakan keadilan menjadi jenis keadilan distributif dan keadilan korektif. Yang pertama berlaku dalam hukum publik, yang kedua dalam hukum perdata dan pidana. Keadilan distributif dan korektif sama-sama rentan terhadap problema kesamaan atau kesetaraan dan hanya bisa dipahami dalam kerangkanya. Dalam wilayah keadilan distributif, hal yang penting ialah bahwa imbalan yang sama-rata diberikan atas pencapaian yang sama rata. Pada yang kedua, yang menjadi persoalan ialah bahwa ketidaksetaraan yang disebabkan oleh, misalnya, pelanggaran kesepakatan, dikoreksi dan dihilangkan.

Keadilan distributif menurut Aristoteles berfokus pada distribusi, honor, kekayaan, dan barang-barang lain yang sama-sama bisa didapatkan dalam masyarakat. Dengan mengesampingkan "pembuktian" matematis, jelaslah bahwa apa yang ada dibenak Aristoteles ialah distribusi kekayaan dan barang berharga lain berdasarkan nilai yang berlaku dikalangan warga. Distribusi yang adil boleh jadi merupakan distribusi yang sesuai degan nilai kebaikannya, yakni nilainya bagi masyarakat. ${ }^{5}$

Di sisi lain, keadilan korektif berfokus pada pembetulan sesuatu yang salah. Jika suatu pelanggaran dilanggar atau kesalahan dilakukan, maka keadilan korektif berusaha memberikan kompensasi yang memadai bagi pihak yang dirugikan; jika suatu kejahatan telah dilakukan, maka hukuman yang sepantasnya perlu diberikan kepada si pelaku. Bagaimanapun, ketidakadilan akan mengakibatkan terganggunya "kesetaraan" yang sudah mapan atau telah terbentuk. Keadilan korektif bertugas membangun kembali kesetaraan tersebut. Dari uraian ini nampak bahwa keadilan korektif merupakan wilayah peradilan sedangkan keadilan distributif merupakan bidangnya pemerintah. ${ }^{6}$

Dalam membangun argumennya, Aristoteles menekankan perlunya dilakukan pembedaan antara vonis yang mendasarkan keadilan pada sifat kasus dan yang didasarkan pada watak manusia yang umum dan lazim, dengan vonis yang berlandaskan pandangan tertentu dari komunitas hukum tertentu. Pembedaan ini jangan dicampuradukkan dengan pembedaan antara hukum positif yang ditetapkan dalam undang-undang dan hukum adat. Karena, berdasarkan pembedaan Aristoteles, dua penilaian yang terakhir itu dapat

5 Ibid.hal. 25.

6 Ibid 
menjadi sumber pertimbangan yang hanya mengacu pada komunitas tertentu, sedangkan keputusan serupa yang lain, kendati diwujudkan dalam bentuk perundang-undangan, tetap merupakan hukum alam jika bisa didapatkan dari fitrah umum manusia. ${ }^{7}$

Salah seorang pakar hukum, John Rawls pernah membandingkan berbagai konsep keadilan, beserta kelebihan dan kekurangan masing-masing, dalam bukunya yang sangat terkenal, "A Theory of Justice". Ia ternyata akhirnya lebih memilih dan lebih percaya pada kinerja formal dari hukum, bahkan sampai mengatakan: "where we find formal justice, the rule of law and the honoring of legitimate expectations, we are likely to find substantive justice as well" (ketika kita menemukan keadilan formal, menegakkan rule of law dan mempertahankan dugaan-dugaan yang sah, maka kita kemungkinan besar juga menemukan keadilan substantif). ${ }^{8}$

\section{Keadilan Sosial John Rawls (Keadilan Kontraktual)}

John Rawls menjelaskan teori keadilan sosial sebagai the difference principle dan the principle of fair equality of opportunity. Inti the difference principle, adalah bahwa perbedaan sosial dan ekonomis harus diatur agar memberikan manfaat yang paling besar bagi mereka yang paling kurang beruntung.

Istilah perbedaan sosial-ekonomis dalam prinsip perbedaan menuju pada ketidaksamaan dalam prospek seorang untuk mendapatkan unsur pokok kesejahteraan, pendapatan, dan otoritas. Sementaraitu, the principle offairequality of opportunity menunjukkan pada mereka yang paling kurang mempunyai peluang untuk mencapai prospek kesejahteraan, pendapat dan otoritas. Mereka inilah yang harus diberi perlindungan khusus. Rawls mengerjakan teori mengenai prinsip-prinsip keadilan terutama sebagai alternatif bagi teori utilitarianisme sebagaimana dikemukakan Hume, Bentham dan Mill. Rawls berpendapat bahwa dalam masyarakat yang diatur menurut prinsip-prinsip utilitarianisme, orang-orang akan kehilangan harga diri, lagi pula bahwa pelayanan demi perkembangan bersama akan lenyap. Rawls juga berpendapat bahwa sebenarnya teori ini lebih keras dari apa yang dianggap normal oleh

7 Ibid, hal. 26-27.

8 John Rawls, A Theory of Justice, Revised Edition, (Harvard University Press, Massachusetts, 2000), hal. 52. 
masyarakat. Memang bolehjadi diminta pengorbanan demi kepentingan umum, tetapi tidak dapat dibenarkan bahwa pengorbanan ini pertama-tama diminta dari orang-orang yang sudah kurang beruntung dalam masyarakat. Menurut Rawls, situasi ketidaksamaan harus diberikan aturan yang sedemikian rupa sehingga paling menguntungkan golongan masyarakat yang paling lemah. Hal ini terjadi kalau dua syarat dipenuhi. Pertama, situasi ketidaksamaan menjamin maximum minimorum bagi golongan orang yang paling lemah. Artinya situasi masyarakat harus sedemikian rupa sehingga dihasilkan untung yang paling tinggi yang mungkin dihasilkan bagi golongan orang-orang kecil. Kedua, ketidaksamaan diikat pada jabatan-jabatan yang terbuka bagi semua orang. Maksudnya supaya kepada semua orang diberikan peluang yang sama besar dalam hidup. Berdasarkan pedoman ini semua perbedaan antara orang berdasarkan ras, kulit, agama dan perbedaan lain yang bersifat primordial, harus ditolak.

Lebih lanjut John Rawls menegaskan bahwa program penegakan keadilan yang berdimensi kerakyatan haruslah memperhatikan dua prinsip keadilan, yaitu, pertama, memberi hak dan kesempatan yang sama atas kebebasan dasar yang paling luas seluas kebebasan yang sama bagi setiap orang. Kedua, mampu mengatur kembali kesenjangan sosial ekonomi yang terjadi sehingga dapat memberi keuntungan yang bersifat timbal balik (reciprocal benefits) bagi setiap orang, baik mereka yang berasal dari kelompok beruntung maupun tidak beruntung. ${ }^{9}$ Dengan demikian, prinsip berbedaan menuntut diaturnya struktur dasar masyarakat sedemikian rupa sehingga kesenjangan prospek mendapat hal-hal utama kesejahteraan, pendapatan, otoritas diperuntukkan bagi keuntungan orang-orang yang paling kurang beruntung. Ini berarti keadilan sosial harus diperjuangkan untuk dua hal: Pertama, melakukan koreksi dan perbaikan terhadap kondisi ketimpangan yang dialami kaum lemah dengan menghadirkan institusi-institusi sosial, ekonomi, dan politik yang memberdayakan. Kedua, setiap aturan harus memposisikan diri sebagai pemandu untuk mengembangkan kebijakan-kebijakan untuk mengoreksi ketidak-adilan yang dialami kaum lemah.

9 Lihat pada John Rawls, A Theory of Justice, yang sudah diterjemahkan dalam bahasa indonesia oleh Uzair Fauzan dan Heru Prasetyo, Teori Keadilan, (Yogyakarta: Pustaka Pelajar, 2006). 


\section{Keadilan Sosial Plato ${ }^{10}$}

Plato adalah seorang pemikir idealis abstrak yang mengakui kekuatankekuatan diluar kemampuan manusia sehingga pemikiran irasional masuk dalam filsafatnya. Demikian pula halnya dengan masalah keadilan, Plato berpendapat bahwa keadilan adalah diluar kemampuan manusia biasa. Sumber ketidakadilan adalah adanya perubahan dalam masyarakat. Masyarakat memiliki elemen-elemen prinsipal yang harus dipertahankan, yaitu:

a. Pemilahan kelas-kelas yang tegas; misalnya kelas penguasa yang diisi oleh para penggembala dan anjing penjaga harus dipisahkan secara tegas dengan domba manusia.

b. Identifikasi takdir negara dengan takdir kelas penguasanya; perhatian khusus terhadap kelas ini dan persatuannya; dan kepatuhan pada persatuannya, aturan-aturan yang rigid bagi pemeliharaan dan pendidikan kelas ini, dan pengawasan yang ketat serta kolektivisasi kepentingan-kepentingan anggotanya.

Dari elemen-elemen prinsipal ini, elemen-elemen lainnya dapat diturunkan, misalnya berikut ini:

a. Kelas penguasa punya monopoliterhadap semuahal sepertikeuntungan dan latihan militer, dan hak memiliki senjata dan menerima semua bentuk pendidikan, tetapi kelas penguasa ini tidak diperkenankan berpartisipasi dalam aktivitas perekonomian, terutama dalam usaha mencari penghasilan,

b. Harus ada sensor terhadap semua aktivitas intelektual kelas penguasa, dan propaganda terus-menerus yang bertujuan untuk menyeragamkan pikiran-pikiran mereka. Semua inovasi dalam pendidikan, peraturan, dan agama harus dicegah atau ditekan.

c. Negara harus bersifat mandiri (self-sufficient). Negara harus bertujuan pada autarki ekonomi, jika tidak demikian, para penguasa akan bergantung pada para pedagang, atau justru para penguasa itu sendiri menjadi pedagang. Alternatif pertama akan melemahkan kekuasaan

10 Konsepsi keadilan Plato dapat dilihat dalam bukunya The Republik terjemahan Benjamin Jowett. Dalam bagian awal buku ini plato mengetengahkan dialog antara Socrates dengan Glaucon tentang makna keadilan. Paper lengkap teori Plato ini dapat dilihat dalam Sakuntala, Pemikiran Keadilan (Plato, Aristoteles, dan John Rawls), dikutip dari https:/ / alisafaat.wordpress.com, diakses ppada 14 September 2014. 
mereka, sedangkan alternatif kedua akan melemahkan persatuan kelas penguasa dan stabilitas negaranya. ${ }^{11}$

Untuk mewujudkan keadilan masyarakat harus dikembalikan pada struktur aslinya, domba menjadi domba, penggembala menjadi penggembala. Tugas ini adalah tugas negara untuk menghentikan perubahan. Dengan demikian keadilan bukan mengenai hubungan antara individu melainkan hubungan individu dan negara. Bagaimana individu melayani negara.

Keadilan juga dipahami secara metafisis keberadaannya sebagai kualitas atau fungsi smakhluk super manusia, yang sifatnya tidak dapat diamati oleh manusia. Konsekuensinya ialah, bahwa realisasi keadilan digeser ke dunia lain, di luar pengalaman manusia; dan akal manusia yang esensial bagi keadilan tunduk pada cara-cara Tuhan yang tidak dapat diubah atau keputusankeputusan Tuhan yang tidak dapat diduga. ${ }^{12}$ Oleh karena inilah Plato mengungkapkan bahwa yang memimpin negara seharusnya manusia super, yaitu the king of philosopher. ${ }^{13}$

\section{A. Keadilan Sosial dalam Islam (Keadilan Distribusi Plus)}

Dalam Kamus Besar Bahasa Indonesia, keadilan sosial didefinisikan sebagai sama berat, tidak berat sebelah, tidak memihak, berpihak kepada yang benar, berpegang pada kebenaran. ${ }^{14}$ Secara etimologis, dalam Kamus AlMunawwir, al'adl berarti perkara yang tengah-tengah. ${ }^{15}$ John Rawls menjelaskan teori keadilan sosial sebagai the differences principle dan the principle of fair equality of opportunity. Inti the differences principle, adalah bahwa perbedaan sosial dan

11 Karl R. Popper, 2002, Masyarakat Terbuka dan Musuh-Musuhnya, (The Open Society and Its Enemy), diterjemahkan oleh: Uzair Fauzan, Cetakan I, (Yogyakarta: Pustaka Pelajar, 2002), hal. 110.

12 W. Friedmann, Teori dan Filsafat Hukum, (Legal Theori), Susunan I, diterjemahkan oleh Mohamad Arifin, Cetakan kedua, (Jakarta: PT Raja Grafindo Persada, 1993), hal. 117.

13 Deliar Noer, Pemikiran Politik Di Negeri Barat, Cetakan II Edisi Revisi, (Bandung: Pustaka Mizan, 1993), hal. 1-15.

14 Depdiknas, Kamus Besar Bahasa Indonesia, (Jakarta: Balai Pustaka, 2002), hal. 8

15 Ahmad Warson Al-Munawwir, Kamus Al-Munawwir Arab-Indonesia Terlengkap, (Yoggyakarta: Pustaka Progressif, 1997), hal. 906 
ekonomis harus diatur agar memberikan manfaat yang paling besar bagi mereka yang paling kurang beruntung. ${ }^{16}$

Keadilan biasa dimaknakan dengan memberikan hak kepada yang berhak (yu'thi alhaqq haqqahu) atau meletakkan sesuatu pada tempatnya (wadh'u assyai 'ala maudhi'ihi). Menurut Syed Muhammad Naquib Al-Attas (1992), secara bahasa keadilan pada umumnya adalah tentang; (i) pengetahuan dan kemampuan untuk menempatkan yang betul dan wajar bagi sesuatu benda atau manusia, (ii) kebenaran yang menentang kesalahan, (iii) cara atau batasan, (iv) keuntungan kerohanian terhadap kerugian, dan (v) kebenaran terhadap kepalsuan.

Dalam ajaran Islam, berkeadilan tertuang dalam dalam al-Qur'an surah alHadid: 25, yaitu:

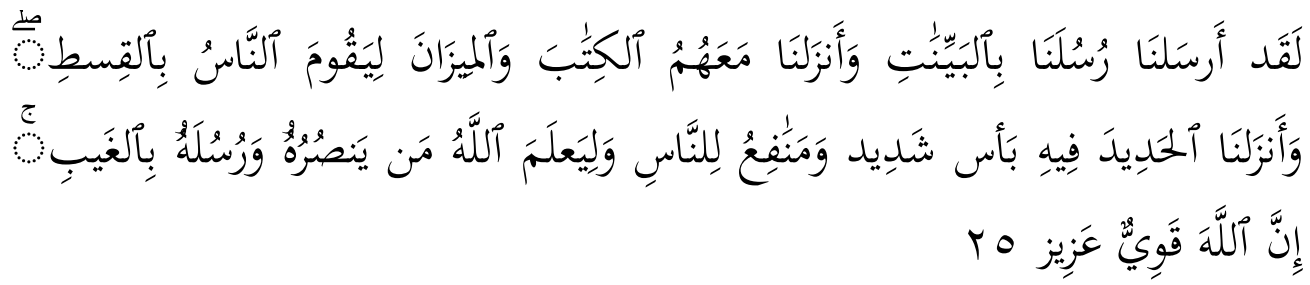

25. Sesungguhnya Kami telah mengutus rasul-rasul Kami dengan membawa buktibukti yang nyata dan telah Kami turunkan bersama mereka Al Kitab dan neraca (keadilan) supaya manusia dapat melaksanakan keadilan. Dan Kami ciptakan besi yang padanya terdapat kekuatan yang hebat dan berbagai manfaat bagi manusia, (supaya mereka mempergunakan besi itu) dan supaya Allah mengetahui siapa yang menolong (agama)Nya dan rasul-rasul-Nya padahal Allah tidak dilihatnya. Sesungguhnya Allah Maha Kuat lagi Maha Perkasa.

Ayat tersebut menegaskan bahwa penegakan keadilan telah ditekankan oleh al-Qur'an sebagai misi utama para Nabi yang diutus Allah swt, termasuk penegakan keadilan ekonomi dan penghapusan kesenjangan pendapatan. Allah yang menurunkan Islam sebagai sistem kehidupan bagi seluruh umat manusia, menekankan pentingnya penegakan keadilan dalam setiap sektor, baik ekonomi, politik maupun sosial. Komitmen al-Qur'an tentang penegakan

16 John Rawls, A Theory of Justice, (London: Oxford University press, 1973), yang sudah diterjemahkan dalam bahasa indonesia oleh Uzair Fauzan dan Heru Prasetyo, Teori Keadilan, (Yogyakarta: Pustaka Pelajar, 2006). 
keadilan sangat jelas. Hal itu terlihat dari penyebutan kata keadilan di dalam al-Qur' an mencapai lebih dari seribu kali yang berarti; kata urutan ketiga yang banyak disebut al-Qur'an setelah kata Allah dan 'Ilm. ${ }^{17}$ Bahkan Ali Syariati menyebutkan, dua pertiga ayat-ayat al-Qur'an berisi tentang keharusan menegakkan keadilan dan membenci kezhaliman, dengan ungkapan kata zhulm, itsm, dhalal, dan lain-lain. ${ }^{18}$

Tabel 1

Beberapa ayat al-Qur'an tentang keadilan

\begin{tabular}{|l|l|}
\hline \multicolumn{1}{|c|}{ Al-Qur'an } & \multicolumn{1}{c|}{ Kandungan } \\
\hline al-Maidah : 8 & $\begin{array}{l}\text { Manusia yang memiliki kecenderungan mengikuti hawa nafsu, } \\
\text { wujudnya kecintaan dan kebencian menyebabkan manusia } \\
\text { tidak bertindak adil dan mendahulukan kebatilan daripada ke- } \\
\text { benaran (dalam bersaksi). }\end{array}$ \\
\hline al- An'am : 152 & $\begin{array}{l}\text { Perintah kepada manusia agar berlaku adil dalam segala hal } \\
\text { terutama kepada mereka yang mempunyai kekuasaan atau } \\
\text { yang berhubungan dengan kekuasaan dan dalam bermua- } \\
\text { malah/berniaga. }\end{array}$ \\
\hline an-Nisa : 128 & Kemestian berlaku adil kepada sesama isteri. \\
\hline al-Hujurat: 9 & Keadilan sesama muslim. \\
\hline al-An'am: 52 & $\begin{array}{l}\text { Keadilan yang berarti keseimbangan antara kewajiban yang } \\
\text { harus dipenuhi manusia (mukalaf) dengan kemampuan manu- } \\
\text { sia untuk menunaikan kewajipan tersebut. }\end{array}$ \\
\hline an-Nisa' : 58 & $\begin{array}{l}\text { Perintah menyampaikan amanat kepada yang berhak meneri- } \\
\text { manya. } \\
\text { Perintah menetapkan dan menerapkan hukum antara manusia } \\
\text { secara adil. }\end{array}$ \\
\hline
\end{tabular}

Fondasi utama ekonomi Islam adalah Tauhid yang mempunyai hubungan kuat dengan konsep keadilan sosio-ekonomi dan persaudaraan. Ekonomi Tauhid yang mengajarkan bahwa Allah sebagai pemilik mutlak dan manusia hanyalah sebagai pemegang amanah, mempunyai konsekuensi, bahwa di dalam harta yang dimiliki setiap individu terdapat hak-hak orang lain yang harus dikeluarkan sesuai dengan perintah Allah, berupa zakat, infaq dan sedekah dan cara-cara lain untuk melaksanakan pendistribusian pendapatan yang sesuai dengan konsep persaudaraan umat manusia. ${ }^{19}$

17 Suryani, "Keadilan Ekonomi dalam Perspektif Ekonomi Syariah: Sebuah Tinjauan Teori", dalam Jurnal Maksimum, Vol 2, No 1 Tahun 2011.

18 Majid Kahduri, The Islamic Conception of Justice, (London: The John Hopkins University Press, 1984), p. 10.

19 Suryani... hal.6 
Keadilan sosial dalam Islam merupakan iIKmplikasi dari prinsip fundamental yang mendasari seluruh ajaran Islam, yakni tauhid. Tauhid bukanlah ajaran abstrak dan 'melangit' semata, akantetapi berhubungan langsung dengan persoalan kehidupan individual dan sosial, serta mengilhami rasa tanggung jawab sosial terhadap orang-orang yang membutuhkan atau berkekurangan. Jika Allah sebagai satu-satunya pencipta, maka seluruh ciptaannya adalah sama (egaliter) memiliki hak karunia-Nya. Semua pernyataan tadi diperkuat dengan keharusan mengimani akan Hari Pengadilan (yaumul hisab) sebagai pertanggungjawaban setiap individu terhadap-Nya. Sebab implikasi penolakan terhadap Hari kiamat adalah melemah bahkan hilangnya rasa tanggung jawab dan tidak peduli terhadap seruan berbuat baik kepada kaum yang lemah (dhu'afa). Oleh karenanya, sejak awal sekali al-Quran menuduh politeisme (syirk) masyarakat Mekkah yang menjadi gejala segmentasi masyarakat dan ketimpangan sosial adalah sebab utama kebangkrutan sosial dan hilangnya rasa solidaritas antar sesama.

Karenanya keprihatinan Islam di Mekkah pada masa awalnya adalah politeisme dan kezaliman sistem ekonominya. Perilaku politeisme dipandang sebagai dosa tak terampuni (QS 4:48,116) dan sebagai kejahatan manusia terbesar terhadap dirinya sendiri (QS.31:13). Implikasi politeisme, tidak adanya iman Hari kepada Hari Kiamat ini bukan saja menimbulkan kepincangan sosial tetapi juga menumpuk sikap individualistis dan menimbun kekayaan sebanyak mungkin, penindasan terhadap kaum lemah, bahkan berakibat terhadap pandangan bahwa dengan kekayaan seseorang dapat hidup secara abadi tanpa sangsikeagamaan apa pun, "Dan mereka berkata: 'kami lebih banyak mempunyai harta dan anak-anak dan sekali-kali kami tidak akan diazab" (QS. 34:35). ${ }^{20}$

Dari uraian diatas, dapat simpulkan bahwa teori keadilan dalam Islam lebih dekat dengan terori keadilan distribusi yang kemudian disebut dengan keadilan distribusi plus. Konsep keadilan distributif menurut Tang dan Sarsfield Baldwin (1996) yaitu keadilan distibutif berhubungan dengan hasil yang akan dicapai pada akhirnya, yaitu keputusan apa yang telah dibuat (what the decisions are). ${ }^{21}$

20 Ibid

${ }^{21}$ Lihat Tang, T.L-P., and Sarsfield Baldwin, L.J., “Distributive and procedural justice as related to satisfaction and commitment". S.A.M. Advanced Management Journal 61(3), 1996, p.25-31. 
Bass (2003) menyatakan bahwa prinsip spesifik dalam keadilan distributif adalah: (1) Batasan egalitarian, yaitu setiap orang harus diperlakukan secara adil karena sumbangsihnya terhadap kehidupan masyarakat sehingga memberikan keuntungan maupun akumulasi-akumulasi tertentu; (2) Kontribusi, yaitu setiap orang seharusnya mendapatkan keuntungan karena sumbangsihnya terhadap tujuantujuan yang telah sebelumnya ditetapkan oleh kelompoknya, melalui: (a) Upaya kerja keras: orang yang bekerja keras patut untuk mendapatkan penghargaan yang lebih banyak; (b) Hasil/ produktivitas, yaitu tingginya kuantitas maupun kualitas hasil kerja individual mempengaruhi penghargaan yang diperolehnya; (c) Permintaan kepuasan, yaitu orang yang memperoleh penghargaan adalah orang yang telah mampu memberikan kepuasan bagi kepentingan-kepentingan publik. Misalnya, dalam dunia pemasaran yang sangat kompetitif, pemenang pasar ialah produsen yang mampu menghasilkan barang yang sangat sempurna.

Prinsip spesifik keadilan distributif terdiri dari prinsip egalitarianism, perbedaan, sumber, kesejahteraan, desert, libertarian, dan feminis. Prinsip egalitarianism merupakan keadilan distributif yang sifatnya sangat radikal. Prinsipegalitarianismmenyatakanbahwasetiaporang seharusnyamendapatkan jumlah maupun kualitas yang sama ketika sumber-sumber berupa barang maupun pelayanan diberikan. Prinsip ini dapat diberlakukan ketika individu di dalamnya menaruh hormat terhadap prinsip keadilan yang sejajar melalui pemberian barang dan pelayanan yang sama untuk setiap orang dari mana pun golongannya. Masalah-masalah dari penerapan prinsip egalitarianism dalam menerapkan prinsip-prinsip keadilan adalah sebagai berikut ini: (1) Sulit untuk melakukan pengukuran mengenai nilai-nilai keadilan yang sifatnya benarbenar objektif untuk semua orang karena setiap orang mempunyai persepsi yang berbeda mengenai suatu kejadian yang sama; (2) Sulit untuk mendapatkan barangbarang maupun jasa yang kualitasnya benar-benar sama, yang kemudian didistribusikan untuk banyak orang yang membutuhkannya. ${ }^{22}$ Teori keadilan distributif plus yang dimaksud adalah teori keadilan sesuai dengan prinsipprinsip Islam.

22 Yohanes Budiarto dan Rani Puspita Wardani, "Peran Keadilan Distributif, Keadilan Prosedural dan Keadilan Interaksional Perusahaan Terhadap Komitmen Karyawan Pada Perusahaan (Studi Pada Perusahaan X)," Jurnal Psikologi Vol. 3 No. 2, Desember 2005 


\section{Keadilan Sosial dalam Ekonomi Islam}

Mubyarto $^{23}$ membedakan keadilan sosial dengan keadilan ekonomi. Keadilan sosial sangat berkait dengan keadilan distribusi atau pembagian hasil yang adil daripada produksi atau pendapatan nasional. Sedangkan keadilan ekonomi adalah memberikan kesempatan yang sama pada setiap orang untuk melakukan produksi. Keadilan ekonomi (economic justice) dalam Islam ditunjukkan dengan penekanan al-Qur'an pada perlunya persamaan manusia (egalitarianism) dan mengelakkan segala bentuk ketidakseimbangan sosial yang berpunca daripada ketidakseimbangan ekonomi yang disebabkan oleh tindakan tidak beretika seperti eksploitasi, keserakahan, penumpukan harta pada kumpulan tertentu sahaja dan sebagainya. ${ }^{24}$ Dengan demikian, konsep keadilan sosio ekonomi dalam perspektif Islam berasaskan ajaran persaudaraan yang melampaui batas-batas geografis seperti yang dinyatakan dalam alQur'an. ${ }^{25}$ Hal ini juga berasaskan konsep Islam bahawa manusia di hadapan Allah SWT memiliki darjah yang sama.

Secara ekonomi, keadilan mesti ditegakkan dalam dua ranah sekaligus: Keadilansecaraumum(Adl'am) bermakna perwujudansistemdanstrukturpolitik maupun ekonomi yang adil. Ranah ini merupakan tanggungjawab penguasa dan pemerintah. Keadilan secara khusus (Adl khas) bermakna pelaksanaan keadilan dalam kehidupan muamalah antar kaum muslim dan sesama manusia. Adl khas meliputi bidang yang luas seperti larangan melanggar hak orang lain. Islam tidak menghendaki adanya ketimpangan ekonomi antara satu orang dengan yang lainnya. Oleh karenanya salah satu keistimewaan penting dalam sistem ekonomi Islam adalah pengaturan perilaku rakyat dan pemerintahan yang meliputi dua dimensi materi dan spiritual sekaligus. Sebab dalam Islam, tujuan utama adalah mengantarkan manusia kepada kesempurnaan ruhani dan spiritual. Karena itu dalam sistem ekonomi Islam mekanisme yang dijalankan adalah untuk mendukung terwujudnya tujuan itu. Dua dimensi materi

\footnotetext{
23 Mubyarto, 1990, Sistem dan Moral Ekonomi Indonesia, (Jakarta: LP3ES, 1990), hal 23.

24 Amiur Nuruddin, Konsep Keadilan dalam Al-Quran dan Implikasinya pada Tanggung Jawab Moral, (Yogyakarta: Disertasi Program Pascasarjana IAIN Sunan Kalijaga, 1994), hal 233.

25 Al-Qur'an Surah al-Hujarat: 13 dan al-Maidah: 8.
} 
dan spiritual itu nampak jelas dalam ajaran Islam yang melarang monopoli, penimbunan harta (al-Ihtikar) dan perintah mengeluarkan zakat dan sedekah.

Larangan demikian ditemukan dalam al-Qur'an. Allah SWT berfirman: Apa saja harta rampasan (fay') yang diberikan Allah kepada Rasul-Nya yang berasal dari penduduk kota-kota maka adalah untuk Allah, Rasul, kerabat Rasul, anakanak yatim, orang-orang miskindan orang-orang yang dalam perjalanan; supaya harta itu jangan hanya beredar di antara orang-orang kaya di antara kalian saja. (QS.59: 7). Nabi Muhammad Saw juga bersabda: Tidak menimbun barang kecuali orangorang yang berdosa. (HR. Muslim). Orang yang bekerja itu diberi rizki, sedang orang yang menimbun itu diberi laknat. (HR. Ibnu Majah). Siapa saja yangmenyembunyikan/al ihtikar (gandum atau barang-barang keperluan lainnya dengan mengurangi takaran dan menaikkan harganya), maka dia termasuk orang- orang yang zalim. ${ }^{26}$

Sedangkan keadilan ekonomi (economic justice) mengandung pengertian bahwa al-Qur'an sangat menekankan persamaan manusia (egalitarianism) dan menghindarkan segala bentuk kepincangan sosial yang berpangkal dari kepincangan ekonomi, seperti eksploitasi, keserakahan, konsentrasi harta pada segelintir orang dan lain sebagainya.22 Tegasnya manusia dihadapan Allah SWT memiliki derajat yang sama, tanpa ada yang boleh merasa lebih mulia dari yang lain. Kesadaran setara dihadapan Allah ini harus menjadi kesadaran internal bagi setiap manusia untuk berwawasan egalitarian (almusawah) dengan tidak membeda-bedakan orang berdasarkan primordial yang dimilikinya seperti ras, agama, dan suku. Manusia hanya bisa diperlakukan secara berbeda hanya berdasarkan kualitas-kualitas objektif yang dimilikinya atau berdasarkan perbuatan-perbuatan yang dilakukannya. Wawasan terhadap manusia yang seperti inilah yang memungkinkan keadilan sosial-ekonomi dapat ditegakkan. ${ }^{27}$

Islam tidak menuntut adanya pemerataan kekayaan dalam arti yang sebenarnya secara harfiyah, karena distribusi kekayaan tergantung pada kemampuan masing-masing individu yang satu sama lain tidak seragam. Dengan demikian keadilan dalam arti yang mutlak menuntut agar imbalan

26 Bayu Taufiq Possumah, Ekonomi Islam dan Keadilan Sosial, Paper pada Research Center for Islamic Economic and Finance (EKONIS) Universitas Kebangsaan Malaysia, tt.

27 Suryani....hal.14 
kepada semua orang sama-sama berbeda, dan bahwa sebagian di antara mereka mendapatkan imbalan lebih besar daripada yang lain selama keadilan dalam arti kemanusiaan itu dipertahankan dengan disediakannya kesempatan yang sama bagi semua orang. Jadi tingkat atau kedudukan seseorang, asal-usul atau kelas dalam masyarakat jangan sampai menghalangi siapa saja untuk mendapatkan kesempatan itu, atau jangan sampai ada orang yang terhalang kesempatannya untuk berusaha karena belenggu itu. Keadilan juga harus dipertahankan dengan segala macam nilai yang berlaku, dan engan pembebasan fikiran manusia secara tuntas dari pelaksanaan nilai-nilai ekonomik murni secara sewenang-wenang, serta dengan meletakkan kembali nilai-nilai ditempatnya yang wajar. Nilai-nilai ekonomik secara intrinsik tidak boleh ditempatkan pada posisi yang tinggi, sehingga menguasai posisi masyarakat yang tidak memiliki nilai-nilai yang pasti atau yang kurang memperhatikannya; sehingga dalam kondisi semacam itu uang merupakan satu-satunya nilai yang paling tinggi dan azasi. ${ }^{28}$

Keadilan ekonomi dalam ajaran Islam dapat dipaparkan dalam beberapa hal. Pertama, seluruh anggota masyarakat mesti memperoleh kesejahteraan yang memadai. Kedua, perbedaan dalam hal pendapatan hendaknya bukan terjadi akibat praktik diskriminasi dalam undang-undang dan kesempatan memperoleh fasilitas dan kesempatan. Selain itu, kalangan kaya hendaknya menunaikan tugas dan kewajibannya terkait hak kaum miskin dan hak pemerintahan Islam. Dalam sistem ekonomi Islam, kemajuan jangan sampai berakibat buruk pada pendistribusian kekayaan secara adil. Sebab kemajuan dan pertumbuhan ekonomi tak lain adalah sarana untuk mewujudkan keseimbangan dan keadilan ekonomi. Imam Ali (as) berkata, "Tak ada sesuatu yang berkesan dalam memakmurkan negeri lebih dari keadilan." (Al-Hayat: juz: 6 hal: 407). Ungkapan ini menjelaskan bahwa dalam Islam keadilan adalah syarat yang mesti dipenuhi untuk meraih kekayaan dan kemakmuran.

Chapra mendefinisikan ekonomi Islam sebagai berikut: "Islamic economics may than be defined as a branch of knowledge which helps realize human well-being through an allocation and distribution of scarce resources that is in conformity with

${ }^{28}$ Sayyid Qutb, "Keadilan Sosial dalam Islam", dalam John J. Donohue dan John L. Esposito, Islam dan Pembaharuan, Terj. Machnun Husein, (Jakarta: CV Rajawali, 1984), hal. 224. 
Islamic teachings without unduly curbing individual freedom or creating continued macroeconomic and ecological imbalances." 29 Definisi tersebut mengisyaratkan bahwa ekonomi Islam merupakan suatu cabang ilmu pengetahuan untuk membantu merealiasaikan kesejahteraan manusia melalui alokasi dan distribusi sumber-sumber daya langka yang seirama dengan tujuan syariat atau maqasid asy-syariah (selanjutnya disebut maqasid) tanpa mengekang kebebasan individu, menciptakan ketidakseimbangan makro-ekonomi dan ekologi, atau melemahkan solidaritas keluarga dan sosial serta jaringan moral masyarakat. ${ }^{30}$ Dengan demikian titik point pemikiran ekonomi Islam Chapra adalah terwujudnya kesejahteraan yang digali dari konsep maqasid. ${ }^{31}$

Konsep ini menghendaki lahirnya pemikiran yang proporsional tentang keadilan dalam kehidupan manusia, artinya bagaimana membentuk dan melaksanakan hukum sebagai upaya mewujudkan kemaslahatan manusia dalam arti luas. Konsep ini telah diakui oleh para ulama dan oleh karena itu mereka memformulasikan suatu kaidah yang cukup populer,"Di mana ada maslahat, di sana terdapat hukum Allah." 32 Teori maslahat di sini menurut Masdar F. Mas'udi sama dengan teori keadilan sosial dalam istilah filsafat hukum. ${ }^{33}$

Sejak awal syari'ah Islam sebenarnya tidak memiliki tujuan lain kecuali kemaslahatan manusia. Ungkapan standar bahwa syari'ah Islam dicanangkan demi kebahagiaan manusia, lahir-batin; duniawi-ukhrawi, sepenuhnya mencerminkan maslahat. Akan tetapi keterikatan yang berlebihan terhadap nas, seperti dipromosikan oleh faham ortodoksi, telah membuat prinsip maslahat hanya sebagai jargon kosong, dan syari'ah yang pada mulanya adalah jalantelah menjadi jalan bagi dirinya sendiri. ${ }^{34}$

${ }_{29}$ M. Umer Chapra, What is Islamic Economics?, (Jeddah, Saudi Arabia: IRTI-IDB, 1996), hal. 33 .

${ }^{30}$ M. Umer Chapra, The Future of Economics: An Islamic Perspective, (Leicester, UK: The Islamic Foundation, 2000), hal. 125

31 M.Umer Chapra, Islam and the Economic Challenge, (Herndon: the International Institute of Islamic Thought, 1992), hal. 7. Lihat juga M.Umer Chapra, Islam and Economic Development, (Islamabad: the International Institute of Islamic Thought, 1993), hal. 6

32 Muhammad Sa'id Ramdan al-Buti, Dawabit al-Maslahah fi as-Syariah al-Islamiyah, (Beirut: Mu'assasah ar-Risalah, 1977), hal.12.

33 Masdar F. Mas'udi, "Meletakkan Kembali Maslahat Sebagai Acuan Syari'ah" Jurnal Ilmu dan Kebudayaan Ulumul Qur'an No.3, Vol. VI Th. 1995. hal. 97

34 Ibid, hal. 94 
Maqasid mengandung semua yang diperlukan manusia untuk merealisasikan kesejahteraan hidup di dunia dan akhirat dalam batas syariat. Al-Syatibi (w. 1388) menyatakan bahwa tujuan akhir syariat adalah maslahah atau kebaikan dan kesejahteraan seluruh umat manusia. Kemaslahatan tersebut merupakan hasil dari pembacaan -sebagaimana yang dikatakan oleh al-Syatibi, ${ }^{35}$ yaitu menjaga agama, jiwa, keturunan, harta dan akal. Ini berarti bahwa dalam maslahah daruriyyat terdapat lima tujuan, yaitu menjaga agama (hifz ad-din), menjagajiwa (hifz al-nafs), menjaga keturunan (hifz al-nasl), menjaga harta (hifz almal), dan menjaga akal (hifz al-aql). Kelima hal tersebut sering dijelaskan dengan konsep al-kulliyat al-khamsah, atau lima prinsip yang mendasari keseluruhan hukum dan ketentuan-ketentuan dalam Islam. Kategorisasi kemaslahatan daruriyyat ini merupakan terminologi yang sebelumnya pernah diungkapkan oleh al-Juwaini dalam bukunya al-Burhan fi Usūl al-Fiqh. ${ }^{36}$

Konsep keadilan sosio-ekonomi yang diajarkan Islam menginginkan adanya pemerataan pendapatan secara proporsional. Dalam tataran ini, dapat pula dikatakan bahwa ekonomi Islam adalah ekonomi yang dilandaskan pada kebersamaan. Karena itu tidak aneh, jika anggapan yang menyatakan bahwa prinsip keadilan sosio-ekonomi Islam mempunyai kemiripan dengan sistem sosialisme. Bahkan pernah ada pendapat yang menyatakan bahwa sistem sosialisme itu jika ditambahkan dan dimasukkan unsur-unsur Islam ke dalamnya, maka ia menjadi islami.

Dalam ekonomi Islam, penegakan keadilan sosio-ekonomi dilandasi oleh rasa persaudaraan (ukhuwah), saling mencintai (mahabbah), bahu-membahu (takaful) dan saling tolong-menolong ( ta $\left.^{\prime} a w u n\right)$, baik antara si kaya dan si miskin maupun antara penguasa dan rakyat.

\section{E. Keadilan dalam Sistem Keuangan Syariah}

Pada dasarnya ekonomi Islam merupakan sistem ekonomi yang berdiri tegak pada dasar-dasar kebersamaan dan keadilan dalam mencapai tujuan.

35 Asy-Syātibi, al-Muwāafaqat fi Ushūl al-Syarī'ah, (Beirut: Dār al-Kutub al-'Ilmiyah, 2003), hal.20

36 Di samping pembagian tersebut, masyaqah (kesukaran) juga dibagi menjadi dua kategori, yaitu; mulazimah li at-Taklif (selalu mengikuti pembebanan hukum) dan ghairu mulazimah laha (tidak selalu mengikuti pembebanan hukum). Istilah ini digunakan oleh al Izz bin Abd. Salam dalam bukunya Qawaid al Ahkam. 
Paling tidak terdapat empat prinsip yang melandasi praktik ekonomi Islam. Pertama; anjuran membelanjakan harta dijalan Allah semaksimal mungkin untuk tercapainya keadilan dan kesejahteraan sosial. Malalui prinsip ini kemudian terejawantahkan konsep zakat, sedekah, infak, wakaf dan sebagainya. Pada dasarnya Islam tidak mentolerir terjadinya kesenjangan mencolok antara kaum the have dengan kalangan the have not.

Kedua; larangan untuk melakukan riba. Para ulama berbeda pendapat dalam menyikapi apakah bunga bank termasuk riba. Namun demikian pada dasarnya mereka sama-sama sepakat bahwa apabila ada dua orang melakukan transaksi (bisnis) tidak boleh ada salah seorang diperlakukan "kalah" sehingga muncul skema win-lose, salah seorang menderita kerugian dari pada yang lain. Sehingga muncul ketidakadilan dalam menanggung resiko.

Lalu muncul prinsip ketiga; membagi resiko bersama (risk sharing). Jika suatu usaha yang dikelola bersama mengalami kerugian maka para pihak dapat menanggung resiko secara bersama-sama secara adil dan bijaksana, tidak boleh salah satu pihak merasa tidak puas karena didzholimi. Terkait prinsip ketiga maka terdapat prinsip keempat yaitu melarang terjadinya eksploitasi dari satu manusia pada manusia lainnya. Artinya, salah satu pihak yang bersepakat untuk suatu usaha (bisnis) tidak boleh menjadi kaya sendiri sementara pihak lain dalam situasi menderita. Dalam konteks ini maka pembagian keuntungan yang berat sebelah dalam suatu kontrak karya (proyek bisnis) misalnya bisa disebut sebagai kontrak karya yang bertentangan dengan prinsip ajaran Islam.

Prinsip kelima adalah larangan melakukan usaha yang bersifat spekulasi. Contoh kongkrit adalah judi. Setiap usaha telah ditelaah, direncanakan matang, tertata baik dan logis, lalu prediksi dan antisipasi dilakukan sesuai prinsip rasionalitas bukan didasarkan perilaku spekulatif yang nir data dan informasi tidak akurat. Prinsip ini merupakan pengejawantahan manajemen modern. Namun manusia acapkali serakah dan amoral yang membuat prinsip diatas terabaikan. $^{37}$

Setidaknya, ada tiga asas filsafat ekonomi syari'ah. ${ }^{38}$ Pertama, semua yang ada di alam semesta ini adalah milik Allah SWT. Manusia hanyalah

37 Suryani...hal.9

38 MN Harisudin, "Ekonomi Shariah dan Ketidakadilan Kapitalisme Global, dalam Jurnal ISLAMICA, Vol. 5, No. 2, Maret 2011, hal. 240-242. 
khalifah yang memegang amanah dari Allah SWT untuk menggunakan milikNya. Sehingga segala sesuatu harus tunduk pada Allah Sang Pencipta dan pemilik. (QS:Al-Najm: 31). Kedua, untuk dapat melaksanakan tugasnya sebagai khalifah Allah, manusia wajib tolong-menolong dan saling membantu dalam melaksanakan kegiatan ekonomi yang bertujuan untuk beribadah pada Allah. Ketiga, beriman pada hari kiamat yang merupakan asas penting dalam sistem ekonomi shariah. Dengan keyakinan seperti ini, tingkah laku manusia akan dapat terkendali. Sebab ia sadar bahwa semua perbuatannya akan dimintai pertanggung jawabannya kelak oleh Allah SWT. ${ }^{39}$ Di bawah tiga filsafat pokok ini, ada beberapa nilai dalam ekonomi shariah, sebagaimana berikut:

1. Nilai dasar kepemilikan, menurut sistem ekonomi syari'âh:

a. Kepemilikan bukan penguasaan mutlak atas sumber-sumber ekonomi, tetapi setiap orang atau badan dituntut kemampuannya untuk memanfaatkan sumber-sumber ekonomi tersebut.

b. Lama kepemilikan manusia atas sesuatu benda terbatas pada lamanya manusia hidup di dunia.

c. Sumber daya yang menyangkut kepentingan umum, seperti air, rumput, api, minyak, gas bumi, dan kebutuhan pokok lainnya harus menjadi milik umum.

2. Keseimbangan yang terwujud pada kesederhanaan, hemat dan menjauhi sikap pemborosan. (QS. Al-Furqan: 67).

3. Keadilan dalam kehidupan ekonomi seperti proses distribusi, produksi, konsumsi dan lain sebagainya. Keadilan juga diwujudkan dalam mengalokasikan kegiatan ekonomi tertentu bagi orang yang tidak mampu memasuki pasar melalui zakat, infak, dan hibah. ${ }^{40}$

Ketiga nilai di atas, pada tahapan selanjutnya, menjadi inti dalam berbagai terapan ekonomi syari'âh. Bank syari'âh misalnya. Dalam bank ini, dikembangkan sistem yang berkeadilan yang disebut dengan profit sharing (bagi hasil). Jika sistem kapitalisme menggunakan piranti bunga sebagai suatu yang built in dalam bank konvensional, maka bank syari'âh menggesernya dengan

39 Nurul Huda et.al, Ekonomi Makro Islam: Pendekatan Teoritis. (Jakarta: Kencana, 2008), hal. 3 dan 4 .

40 Ibid, hal. 4 
sistem bagi hasil. Sistem bagi hasil merupakan bentuk eksplisit anti-riba yang sejak awal ditentang oleh bank syari'âh. Karena, Islam secara tegas, melarang umatnya untuk memberi, mengambil atau memakan riba. ${ }^{41}$ Dalam bunga bank konvensional, pemilik modal adalah orang yang sangat diuntungkan karena dalam kondisi apapun ia tetap akan memperoleh bunga tanpa usaha dan berkeringat. ${ }^{42}$

Seorang pengusaha yang mendepositokan uang 100 milyar misalnya, seumur hidup tanpa bekerja, ia sudah mendapatkan uang yang mengucur deras dari bank tempat ia menaruh uangnya. Bandingkan dengan para tukang becak yang seharian berpeluh keringat hanya mendapat uang Rp. 20.000,- kalau nasib untung. Padahal, sang tukang becak juga bisa tidak mendapatkan apaapa seharian bekerja. ${ }^{43}$

Al-Razi sebagaimana dikutip Lewis dan Algaoud mengemukakan beberapa alasan pelarangan riba antara lain: pertama, riba tak lain adalah perampasan hak milik orang lain tanpa ada nilai imbangan; kedua, riba dilarang karena menghalangi orang dari keikutsertaan dalam profesi-profesi aktif; ketiga, perjanjian riba menimbulkan hubungan yang tegang antara sesama manusia; keempat, perjanjian riba adalah alat yang digunakan orang kaya untuk mendapatkan kelebihan dari modal dan ini bertentangan dengan keadilan dan persamaan; dan kelima, keharaman riba dinyatakan oleh nas Al-Qur'an dan manusia tidak harus mengetahui alasannya. ${ }^{44}$

Dengan melarang riba, Islam berusaha membangun sebuah masyarakat berdasarkan kejujuran dan keadilan. ${ }^{45}$ Keadilan dalam konteks ini memiliki dua dimensi, yaitu pemodal berhak untuk mendapatkan imbalan, tetapi harus

${ }^{41}$ Sudin Haron, Prinsip dan Operasi Perbankan Islam, (Kuala Lumpur: Berita Publishing, 1996). Bandingkan dengan Analisis Kritis Abdullah Saeed, 1996, Islamic Banking and Interest, A Studi of The Prohibition of Riba and Its Contemporary Interpretation, (Netherland: Studies in Islamic Law and Society, 1996), hal. 17-39.

${ }^{42}$ Ibid

43 Suryani....hal. 19

${ }_{44}$ Mervvyn Lewis dan Latifa Algaoud, Perbankan Syariah: Prinsip, Praktek, dan Prospek, (Jakarta: PT. Serambi Ilmu Semesta, cet. II, 2004), hal. 61-62.

45 Konsep perbankan dalam Islam bersandar pada keadilan dan keharmonisan antara realita dan keinginan manusia, artinya, perbankan Islam mencoba menjembatani antara realita dan hasrat manusia untuk mendapatkan keuntungan namun dalam kerangka yang adil. Lihat Masyhuri (Ed), Teori Ekonomi dalam Islam, (Yogyakarta: Kreasi Wacana, 20055), hal. 138. 
sepadan dengan resiko dan usaha yang dibutuhkan, dan imbalan yang didapat ditentukan oleh keuntungan dari proyek yang dimodalinya. Yang dilarang dalam Islam adalah keuntungan yang ditetapkan sebelumnya.

Di Indonesia bunga bank masih menjadi polemik tersendiri karena para ulama masih belum sepakat tentang boleh-tidaknya sehingga dalam praktek, baik perbankan syariah ${ }^{46}$ maupun perbankan konvensional berjalan bersamasama. Perbedaan pendapat ini diklasifikasikan menjadi tiga pandangan, yaitu: pertama, bunga bank adalah termasuk dalam kategori riba sehingga hukumnya haram, sedikit atau banyak unsur; kedua, bunga bank bukan termasuk dalam kategori riba sehingga halal untuk dilakukan; ketiga, riba termasuk dalam klasifikasi mutasyabihat sehingga sebaiknya bunga bank tidak dilakukan. ${ }^{47}$

Perbedaan pokok antara perbankan syariah dengan perbankan konvensional adalah pada penggunaan bunga dalam pembiayaannya (equity financing). Kalau perbankan konvensional menggunakan sistem bunga, maka perbankan syariah tidak menggunakan bunga tetapi sistem bagi hasil. Mudharabah dan musyarakah atau yang sering dikenal dengan istilah profit and loss sharing (PLS) adalah dua model kerjasama yang direkomendasikan dalam Islam karena bebas dari sistem riba. ${ }^{48}$

\section{Keadilan Sistem Mudharabah.}

Mudharabah berasal dari kata dharb, artinya memukul atau berjalan. Pengertian memukul atau berjalan ini lebih tepatnya adalah proses seseorang menggerakkan kakinya dalam menjalankan usaha. Mudharabah merupakan bahasa penduduk Iraq, sedangkan menurut bahasa penduduk Hijaz disebut

46 Perkembangan bank-bank dengan landasan syariah Islam di berbagai negara dimulai pada dekade 1970-an. Di Indonesia, pendirian bank syariah diprakarsai oleh Majelis Ulama Indonesia (MUI) melalui satu lokakarya yang menghasilkan Tim Perbankan MUI. Tim ini kemudian menghasilkan pendirian Bank Muamalat Indonesia pada 1 November 1991. Namun, Bank Muamalat mulai resmi beroperasi pada 1 Mei 1992 dengan modal awal sekitar Rp 106 miliar. Lihat Mustafa Edwin Nasution (et.al.), Pengenalan Eksklusif Ekonomi Islam, (Jakarta: Kencana Prenada Media Group, cet. II, 2007), hal. 294. Lihat pula Muchammad Parmudi, Sejarah dan Doktrin Bank Islam, Yogyakarta: Kutub, 20005), hal. 55-59.

${ }_{47}$ Muslimin H. Kara, Bank Syariah di Indonesia: Analisis Kebijakan Pemerintah Indonesia Tentang Perbankan Syariah, (Yogyakarta: UII Press, 2005) hal. 80.

48 Suryani....hal. 19 
dengan istilah qirad. Secara teknis, mudharabah adalah akad kerjasama usaha antara dua pihak, dimana pihak pertama bertindak sebagai pemilik dana (shahibul maal) yang menyediakan seluruh modal (100\%), sedangkan pihak lannya sebagai pengelola usaha (mudharib). Keuntungan usaha yang di dapatkan dari akad mudharabah dibagi menurut kesepakatan yang dituangkan dalam kontrak, dan biasanya dalam bentuk persentase.

Mudharabah merupakan satu pembahasan yang banyak diungkap dalam kitab-kitab fiqh klasik. Dewasa ini, wacana tentang Mudharabah menjadi semakin mencuat seiring perkembangan perbankan syari'ah. Dalam lembaga perbankan syari'ah itu, Mudharabah menjadi salah satu kunci penting dalam kajian-kajian lebih komprehensif mengenai perbankan syari'ah. Apa yang dikenal dengan sistem bagi hasil sebagai alternatif sistem bunga dalam perbankan konvensional, sejatinya, dari term Mudharabah ini.

Semua rasanya sepakat bahwa Mudharabah mengandung nilai-nilai luhur kemanusiaan dan perwujudan prinsip keadilan dalam sebuah usaha ekonomi. Heterogenitas tingkat kemakmuran hidup manusia bagian dari realitas kehidupan yang tak terbantahkan sepanjang masa. Mudharabah ada untuk memberikan kesempatan agar heterogenitas itu tidak terlampau curam menghubungkan golongan kaya dengan masyarakat miskin.

Didalam kontrak mudharabah akan melakukan aspek-aspek atau rukun mudharabah atas dasar kesepakatan bersama yaitu; pemilik modal, pelaku usaha/mudharib/agent, proyek yang akan dijalankan, nisbah pembagian keuntungan dan porsi pembagian kerugian jika hal itu terjadi, dan masa kontrak atau perjanjian serta syarat-syarat lain yang mendukung berjalannya kontrak mudharabah. Jika aspek-aspek atau rukun tersebut dipenuhi, maka dimungkinkan dapat memperkecil terjadinya penyimpangan-penyimpangan yang dilakukan oleh pelaku usaha serta dapat mengoptimalkan kontrak mudharabah tersebut. ${ }^{49}$

Disisi lain, kontrak Mudharabah memiliki beberapa kelemahan, namun demikian bila Mudarib mampu membuktikan bahwa dia dapat diandalkan dan berpengalaman serta mempunyai moral yang tinggi di dalam komunitas bisnis maka penyalahgunaan dapat dihindari. Proyek yang dijalankan harus

${ }^{49}$ Muhammad, Manajemen pembiayaan mudharabah di bank syari'ah, (Jakarta: PT. Raja Grafindo Persada, 2008), hal. 5-6 
dapat berkembang dan diperhitungkan secara independen oleh bank yang terlibat atau konsultan-konsultan dari luar. Bank harus memastikan dananya dibelanjakan sepantasnya (sesuai kebutuhan) dan usaha yang dibiayai tersebut dimonitor secara baik dan tepat. ${ }^{50}$

\section{Keadilan dalam sistem Musyarakah}

Kata musyarakah berasal dari kata arab syirkah atau syirikah berarti kemitraan dalam suatu usaha, dan dapat didefinisikan sebagai sebuah bentuk kemitraan di mana dua orang atau lebih menggabungkan modal atau kerja mereka, untuk berbagi keuntungan, menikmati hak-hak dan tanggung jawab yang sama.

Kemitraan-kemitraan yang berdasarkan perjanjian seperti itu dapat dianggap pantas karena para pihak yang terlibat telah dengan sengaja mengadakan sebuah kesepakatan untuk melakukan investasi bersama dan berbagi keuntungan serta resiko. Sebagai acuan bagi pemberian hak keuntungan dari sebuah musyarakah adalah modal, partisipasi aktif dalam bisnis, dan pertanggungjawaban musyarakah. Keuntungan harus didistribusikan di antara para mitra dalam bisnis berdasarkan proporsi yang telah ditetapkan sebelumnya oleh mereka. Bagian keuntungan masing-masing pihak harus dinyatakan sebagai suatu proporsi atau persentase. Namun, kerugian harus dibagi sesuai dengan kontribusi modal. ${ }^{51}$

Melalui ekonomi/kemitraaan akan terbangun pemerataan dan kebersamaan. Dalam mekanisme bank syariah pendapatan bagi hasil ini berlaku untuk produkproduk penyertaan menyeluruh maupun sebagian-sebagian atau bentuk bisnis koperasi (kerjasama); pihak-pihak yang terlibat dalam kepentingan bisnis harus melakukan transparansi dan kemitraan secara baik dan adil..$^{52}$

Musyarakah sebagai salah satu produk berdasarkan kemitraan, jika ingin berhasil, maka implementasinya harus bertumpu kepada persaingan sehat dan mencegah terjadinya penyalagunaan posisi dominan dalam kemitraan usaha, dan yang paling penting adalah mengatasi setiap problem yang terkait dengan

50 Stepahnie Parigi, Des Banques Islamiques, (Paris: Ramsay, 1989), hal. 137

51 Latifa M. Algaoud dan Mervyn K. Lewis, Perbankan Syariah, Prinsip, Praktik, Prospek. (Jakarta: PT. Serambi Ilmu Semesta, 2001), hal. 69.

52 Muhammad, Manajemen Bank Syariah, (Yogyakarta: UPP YKPN, 2002), hal. 102 
perjanjian berdasar akad Musyarakah yang berlandaskan asas keadilan. Disinilah asas keadilan berperan penting, terutama dalam kontrak baku yang dibuat oleh pihak-pihak di dalamnya. Keadilan ini merupakan nilai yang paling utama yang harus tercermin dalam akad..$^{53}$

\section{F. Penutup}

Keadilan sosial sebagai the differences principle dan the principle of fair equality of opportunity. Inti the differences principle, adalah bahwa perbedaan sosial dan ekonomis harus diatur agar memberikan manfaat yang paling besar bagi mereka yang paling kurang beruntung. Dalam ajaran Islam, berkeadilan tertuang dalam dalam al-Qur'an surah al-Hadid: 25, yang menegaskan bahwa penegakan keadilan telah ditekankan oleh al-Qur'an sebagai misi utama para Nabi yang diutus Allah swt, termasuk penegakan keadilan ekonomi dan penghapusan kesenjangan pendapatan. Fondasi utama ekonomi Islam adalah Tauhid yang mempunyai hubungan kuat dengan konsep keadilan sosioekonomi dan persaudaraan. Ekonomi Tauhid yang mengajarkan bahwa Allah sebagai pemilik mutlak dan manusia hanyalah sebagai pemegang amanah, mempunyai konsekuensi, bahwa di dalam harta yang dimiliki setiap individu terdapat hak-hak orang lain yang harus dikeluarkan sesuai dengan perintah Allah, berupa zakat, infaq dan sedekah dan cara-cara lain untuk melaksanakan pendistribusian pendapatan yang sesuai dengan konsep persaudaraan umat manusia.

Keadilan sosial sangat berkait dengan keadilan distribusi atau pembagian hasil yang adil daripada produksi atau pendapatan nasional. Sedangkan keadilan ekonomi adalah memberikan kesempatan yang sama pada setiap orang untuk melakukan produksi. Keadilan ekonomi (economic justice) dalam Islam ditunjukkan dengan penekanan al-Qur'an pada perlunya persamaan manusia (egalitarianism) dan mengelakkan segala bentuk ketidakseimbangan sosial yang berpunca daripada ketidakseimbangan ekonomi yang disebabkan oleh tindakan tidak beretika seperti eksploitasi, keserakahan, penumpukan harta pada kumpulan tertentu sahaja dan sebagainya. Dengan demikian,

53 Dyah Ochtorina Susanti, Asas Keadilan dalam Perjanjian Berdasar Akad Musyarakah pada Pembentukan Perusahaan, (Malang: Disertasi Program Doktor Ilmu Hukum Brawij, 2010). 
konsep keadilan sosio ekonomi dalam perspektif Islam berasaskan ajaran persaudaraan yang melampaui batas-batas geografis seperti yang dinyatakan dalam al-Qur'an. Hal ini juga berasaskan konsep Islam bahwa manusia di hadapan Allah SWT memiliki derajat yang sama.

Dalam konsep keuangan, Islam dengan tegas melarang riba dan berusaha membangun sebuah masyarakat berdasarkan kejujuran dan keadilan. Keadilan dalam konteks ini memiliki dua dimensi, yaitu pemodal berhak untuk mendapatkan imbalan, tetapi harus sepadan dengan resiko dan usaha yang dibutuhkan, dan imbalan yang didapat ditentukan oleh keuntungan dari proyek yang dimodalinya. Sehingga konsep mudharabah dan musyarakah atau yang sering dikenal dengan istilah profit and loss sharing (PLS) adalah kunci jawabanya. Mudharabah mengandung nilai-nilai luhur kemanusiaan dan perwujudan prinsip keadilan dalam sebuah usaha ekonomi. Heterogenitas tingkat kemakmuran hidup manusia bagian dari realitas kehidupan yang tak terbantahkan sepanjang masa. Mudharabah ada untuk memberikan kesempatan agar heterogenitas itu tidak terlampau curam menghubungkan golongan kaya dengan masyarakat miskin. Sedangkan musyarakah adalah konsep ekonomi/ kemitraaan akan terbangun pemerataan dan kebersamaan.

\section{DAFTAR PUSTAKA}

Al-Buti, Muhammad Sa'id Ramdan, 1977, Dawabit al-Maslahah fi as-Syariah alIslamiyah, Beirut: $\mathrm{Mu}^{\prime}$ assasah ar-Risalah

Algaoud, Latifa M. dan Mervyn K. Lewis, 2001, Perbankan Syariah, Prinsip, Praktik, Prospek, Jakarta: PT. Serambi Ilmu Semesta.

Al-Munawwir, Ahmad Warson, 1997, Kamus Al-Munawwir Arab-Indonesia Terlengkap, Yogyakarta: Pustaka Progressif,

Asrori, 2002, "Akuntansi Syariah Bidang Baru Studi Akuntansi dalam Konteks

Epistimologi Islam”, dalam Jurnal Ekonomi dan Manajemen Dinamika, UNNES, Vol.11 No. 2, 2002

Asy-Syātibi, 2003, al-Muwāfaqat fi Ushūl al-Syarī'ah, Beirut: Dār al-Kutub al'Ilmiyah

Budiarto, Yohanes dan Wardani, Rani Puspita, 2005, “Peran Keadilan Distributif, Keadilan Prosedural Dan Keadilan Interaksional Perusahaan Terhadap 
Komitmen Karyawan Pada Perusahaan (Studi Pada Perusahaan X)," Jurnal Psikologi Vol. 3 No. 2, Desember 2005

Chapra, M. Umer, 1992, Islam and the Economic Challenge, Herndon: the International Institute of Islamic Thought , 1996, What is Islamic Economics?, Jeddah, Saudi Arabia: IRTI-IDB -, 2000, The Future of Economics: An Islamic Perspective, Leicester, UK:

The Islamic Foundation

Depdiknas, 2002, Kamus Besar Bahasa Indonesia, Jakarta: Balai Pustaka

Harisudin, MN, 2011, Ekonomi Shariah dan Ketidakadilan Kapitalisme Global, ISLAMICA, Vol. 5, No. 2, Maret 2011

Haron, Sudin, 1996, Prinsip dan Operasi Perbankan Islam, Kuala Lumpur: Berita Publishing.

http:/ / wardahcheche.blogspot.com/2014/01/keadilan-dalam-ekonomiislam.html

Huda. Nurul, et.al, 2008, Ekonomi Makro Islam: Pendekatan Teoritis. Jakarta: Kencana.

Kahduri, Majid, 1984, The Islamic Conception of Justice, London: The John Hopkins University Press

Kara, Muslimin H., 2005, Bank Syariah di Indonesia: Analisis Kebijakan Pemerintah Indonesia Tentang Perbankan Syariah, Yogyakarta: UII Press

Kariyoto,2014,"AkuntansiSyariahdalamPerspektifTeoridanImplementasinya", dalam jurnal JIBEKA, vol. 8, No. 2, Agustus 2014

Lewis, Mervvyn dan Latifa Algaoud, 2004, Perbankan Syariah: Prinsip, Praktek, dan Prospek, Jakarta: PT. Serambi Ilmu Semesta, cet. II

Mas'udi, Masdar F., 1995, "Meletakkan Kembali Maslahat Sebagai Acuan Syari'ah" Jurnal Ilmu dan Kebudayaan Ulumul Qur'an No.3, Vol. VI Th. 1995

Masyhuri (Ed), 2005, Teori Ekonomi dalam Islam, Yogyakarta: Kreasi Wacana Mubyarto, 1990, Sistem dan Moral Ekonomi Indonesia, LP3ES, Jakarta Muhammad, 2008, Manajemen pembiayaan mudharabah di bank syari'ah, Jakarta:

PT. Raja Grafindo Persada. , 2002, Manajemen Bank Syariah, Yogyakarta: UPP YKPN.

Nasution, Mustafa Edwin (et.al.), 2007, Pengenalan Eksklusif Ekonomi Islam, Jakarta: Kencana Prenada Media Group, cet. II 
Nuruddin, Amiur, 1994, Konsep Keadilan Dalam Al-Quran dan Implikasinya Pada Tanggung Jawab Moral, Disertasi pada Program Pascasarjana IAIN Sunan Kalijaga, YogyakartaNoer, Deliar, 1997, Pemikiran Politik Di Negeri Barat, Cetakan II Edisi Revisi, Bandung: Pustaka Mizan

Parmudi, Muchammad, 2005, Sejarah dan Doktrin Bank Islam, Yogyakarta: Kutub

Popper,Karl R., 2 002, Masyarakat Terbuka dan Musuh-Musuhnya, (The Open Society and Its Enemy), diterjemahkan oleh: Uzair Fauzan, Cetakan I, Yogyakarta, Pustaka Pelajar.

Parigi, Stepahnie, 1989, Des Banques Islamiques, Paris: Ramsay

Possumah, Bayu Taufiq, tt, Ekonomi Islam dan Keadilan Sosial, Paper pada Research

Center for Islamic Economic and Finance (EKONIS) Universitas Kebangsaan Malaysia.

Qutb, Sayyid, 1984, “Keadilan Sosial dalam Islam”, dalam John J. Donohue dan John L. Esposito, Islam dan Pembaharuan, Terj. Machnun Husein, CV Rajawali, Jakarta

Rahman, Afzalur, 1995, Doktrin Ekonomi Islam, jilid 1, Terj. Soeroyo, Nastangin, PT.Dana Bhakti Wakaf, Yogyakarta

Rawls, John, 1973, A Theory of Justice, London: Oxford University press, yang sudah diterjemahkan dalam bahasa indonesia oleh Uzair Fauzan dan Heru Prasetyo, 2006, Teori Keadilan, Yogyakarta: Pustaka Pelajar.

Saeed, Abdullah, 1996, Islamic Banking and Interest, A Studi of The Prohibition of Riba and Its Contemporary Interpretation Netherland: Studies in Islamic Law and Society

Sakuntala, 2008, Pemikiran Keadilan (Plato, Aristoteles, dan John Rawls), dalam https://alisafaat.wordpress.com

Suryani, 2011, “Keadilan Ekonomi dalam Perspektif Ekonomi Syariah: Sebuah Tinjauan Teori", dalam Jurnal Maksimum, Vol 2, No 1 Tahun 2011.

Susanti, Dyah Ochtorina, 2010, Asas Keadilan dalam Perjanjian Berdasar Akad Musyarakah pada Pembentukan Perusahaan, Malang: Disertasi Program Doktor Ilmu Hukum Brawijaya.

W. Friedmann, 1993, Teori dan Filsafat Hukum, (Legal Theori), Susunan I, diterjemahkan oleh Mohamad Arifin, Cetakan kedua, Jakarta: PT RajaGrafindo Persada. 